\title{
EFFECT OF DIFFERENT TYPES OF FOOD ON DEVELOPMENTAL STAGES, FECUNDITY AND LIFE TABLE PARAMETERS OF THE ACARID MITE RHIZOGLYPHUS ECHINOPUS (FUMOUZE\&ROBIN, 1868)
}

\author{
H. A. Taha ${ }^{(1)}$, M. Fawzy ${ }^{(1)}$, A. E. El Ghobashy ${ }^{(2)}$ and Zeinab E. Abdel Salam ${ }^{(1)}$ \\ (1) Plant Protection Research Institute, Agric. Res. Center. Dokki, Giza., Egypt \\ (2) Zoology Department, Faculty of Science, Damietta University, Damietta, Egypt.
}

Received: Aug. 16, 2016

Accepted: Aug. 17, 2016

\begin{abstract}
Dry yeast granules, cheese and crushed wheat were tested as a nourishment of Rhizoglyphus echinopus (Fumouze \& Robin, 1868) under laboratory conditions of $25 \pm 1^{\circ} \mathrm{C}$ and $70 \%$ R.H. Statistical analysis of the obtained results showed that developmental stages, fecundity and life table parameters of the acarid mite , $R$. echinopus were significantly different among the three types of food, whereas, the total immature stages were (13.08 \& 11.9), (13.5 \& 12.4) and (16.0 \& 15.8 days) for female and male when fed on dry yeast, cheese and crushed wheat, respectively. Female oviposition period lasted (15.7, 20.3 and 23.00 days) and deposited average numbers of eggs \& a daily rate (245.4 \& 15.86), (190.8 \& 9.4) and (101.5 \& 4.4) eggs, respectively. Obtained data from the biochemical analysis of food composition showed that the dry yeast granules which have the highest protein content (30.63\%) seem to be an attractive and effective diet for rearing the acarid mite, $R$. echinopus in the laboratory.
\end{abstract}

Key words: Life table, acarid mite, Rhizoglyphus, food types, flour mite, cheese, flour

\section{INTRODUCTION}

Mites are one of the major pests that infest a variety of stored products throughout the world. Mites distributional pattern is not constant everywhere, but varies according to the environmental factors, where it either free living (phytophagous, graminivorus, fungivorus and saprophagous), parasitic and predatory mites on other injurious mites or insects, Taha (1985), Mohamed (2003), Putatundia (2005), Habashy (2006) and Mostafa et al. (2006). Mites associated with stored products causing serious variable degree of damage not only they can consume large amounts of stored products, but also contaminate food with their bodies and extractions. During favorable conditions, the mite population in the stored products may markedly increase, making it unsuitable for humane and domestic animal's consumption, Taha (1985), Sallam et al. (2007).

The present work aims to study the effect of different types of food on biological aspects, fecundity, longevity, life span and life table parameters $R$. echinopus under laboratory conditions.

\section{MATERIALS AND METHODS}

A stock culture of $R$. echinopus collected from a flour sample, which collected from Damietta Governorate. Mites were collected in petri-dishes $(6 \mathrm{~cm}$. diameter $\times 1.5 \mathrm{~cm}$. high). Two females and a male from the laboratory culture of $R$. echinopus were isolated in another Petri-dish for 24 hours to obtain the required number of eggs for biological studies. Newly deposited eggs were transferred solitary each to a plastic cell filled partially with a mixture of cement, clay and charcoal $(1.3 \mathrm{~cm}$. diameter $\times 0.4$ $\mathrm{cm}$ high). Newly hatched larvae were fed during their life span on one of tested diets, dry yeast granules, cheese and crushed wheat under laboratory conditions at $25 \pm 1^{\circ} \mathrm{C}$ and $70 \%$ R.H. Thirty replicates were used for each source of diet, investigated twice daily with adding few amounts of different food types and few drops of water as 
required. Biological aspects as fecundity, longevity, life span and life table parameters were studied. Biochemical analysis of food composition, moisture content using the methods described in the AOAC (1990), quantitative determination of lipids according to the method of Schneider et al. (1950), colorimetric determination of total protein, Lowry et al. (1951), carbohydrate content by the method described by James (1995) and ashes was determined according to Pearson (1981). All statistical analyses were calculated, using the computer programs of SPSS (version 20.0 for Windows) and Excel (2010).

\section{RESULTS AND DISCUSSION}

Under laboratory conditions, the three types of food, dry yeast granules, cheese and crushed wheat were found to be suitable for mite survival and development, but the dry yeast granules was the best food for the acarid mite, $R$. echinopus.

\section{Habitat and behavior:}

The mite R.echinopus was found in large numbers inhabiting different stored products such as bran, cheese and flour in different localities (Kafrsaad, Faraskour and El Zarka) of Damietta Governorate. The mite passed through the larval and two nymphal stages (protonymph and tritonymph) before being adults and between each stage of them the individual enters in quiescent period, in which it made a dry hole or crack in the substrate of the rearing cells, ceases feeding and movement. The egg is oval in shape and translucent when newly deposited, before hatching, it changes to pale white and brown spots appear at anterior part of the egg from which the hatching takes place.

\section{Mating:}

Mating process occurred immediately after emergence of adult female. Female needs copulation several times to put all of its eggs. During copulation the male assumed a dorsoposterior position with female. The female can move but in slow motion while the male on its back and then the latter separate and move away from female. Mating lasted about $10-15$ minutes.

\section{Hatching:}

Eggs were laid singly or in clusters and scattered under particles of substrate and sometimes inside food particles, and the eggs are spherical and translucent, then changes to white color and enlarged near the hatching. During hatching the shell rupture through a longitudinal slit from which larva crawls with its legs. This process lasted about 15-20 minutes. The hatching larva stayed inactive for a short period about 5-10 minutes, and then began its activity.

\section{Moulting:}

The immature stages of $R$. echinopus entered the quiescent stage in which the body swelled and enlarged. The quiescent period they never respond to any stimulation. The old skin is rupture gradually from posterior part of the body to the anterior part. During moulting the individual is crawled in a round moving and then in the late of moulting the individual is stopped from moving and the moulting skin become rupture from posterior part. The newly emerged individual kept quite beside its old skin for a short period, then started to move activity searching for food. The moulting period is about 20 to 30 minutes.

\section{Developmental stages:}

As shown in Tables (1\&2) there were significant differences for the influence of different food types on egg incubation period of female and male, under laboratory conditions at $25 \pm 1^{\circ} \mathrm{C}$ and $70 \%$ R.H. Incubation period lasted 4.0, 4.6 \& 7.1 days for female, while it lasted $3.5,4.0 \& 4.1$ days for male when fed on dry yeast, cheese and crushed wheat, respectively. All the selected food was found suitable for mite survival and development. The total immature stages female and male of $R$. echinopus were affected by the types of food; where female duration were $13.08,13.5$ \&16.00 days, while lasted 11.9, $12.4 \& 15.8$ days for male 
when it fed on dry yeast, cheese and crushed wheat, respectively. The male reached the mature stage before female.

Obtained data showed that dry yeast was the faster life cycles $(17.08 \& 15.4)$ than cheese (18.1\&16.4) and the crushed wheat (23.1 \& 19.9) was the longest one for female and male respectively. These results matched with Mathur and Dalal (1985), Taha et al. (2002) and Mahmoud et al., (2013). Also Bielska (1983) and Chmielewski (2001) proved that the type of food affected the duration of the total development cycle. The female and male longevity affected by the food type. These results were coincided with that obtained by Bielska (1983) and Chmielewski (2001). A dry yeast granule was the most attractive food for $R$. echinopus followed by cheese and the least was the crushed wheat. As shown in table (3) the fecundity also $(245.4,190.8 \& 101.5$ eggs) with daily rate (15.86, $9.4 \& 4.43 \mathrm{egg} /$ days) when fed on dry yeast, cheese and crushed wheat, respectively. Thus, the dry yeast stills the best food for the female $R$. echinopus. Fecundity of $R$. echinopus studied also on buckwheat by Chmielewski (2001). R. echinopus life span durations were significantly affected by different diets which were $39.38,45.1$ \&54.00 days for female, while it was 34.1 , 40.3 \& 47.4 days when fed on dry yeast, cheese and crushed wheat, respectively. These results were coincided by Bielska (1983) and Chmielewski (2001).

Table (1): Duration of different stages of Rhizoglyphus echinopus female fed on different food types at $25 \mathrm{C}^{\circ}$ and $65 \% \pm 5 \%$ R.H.

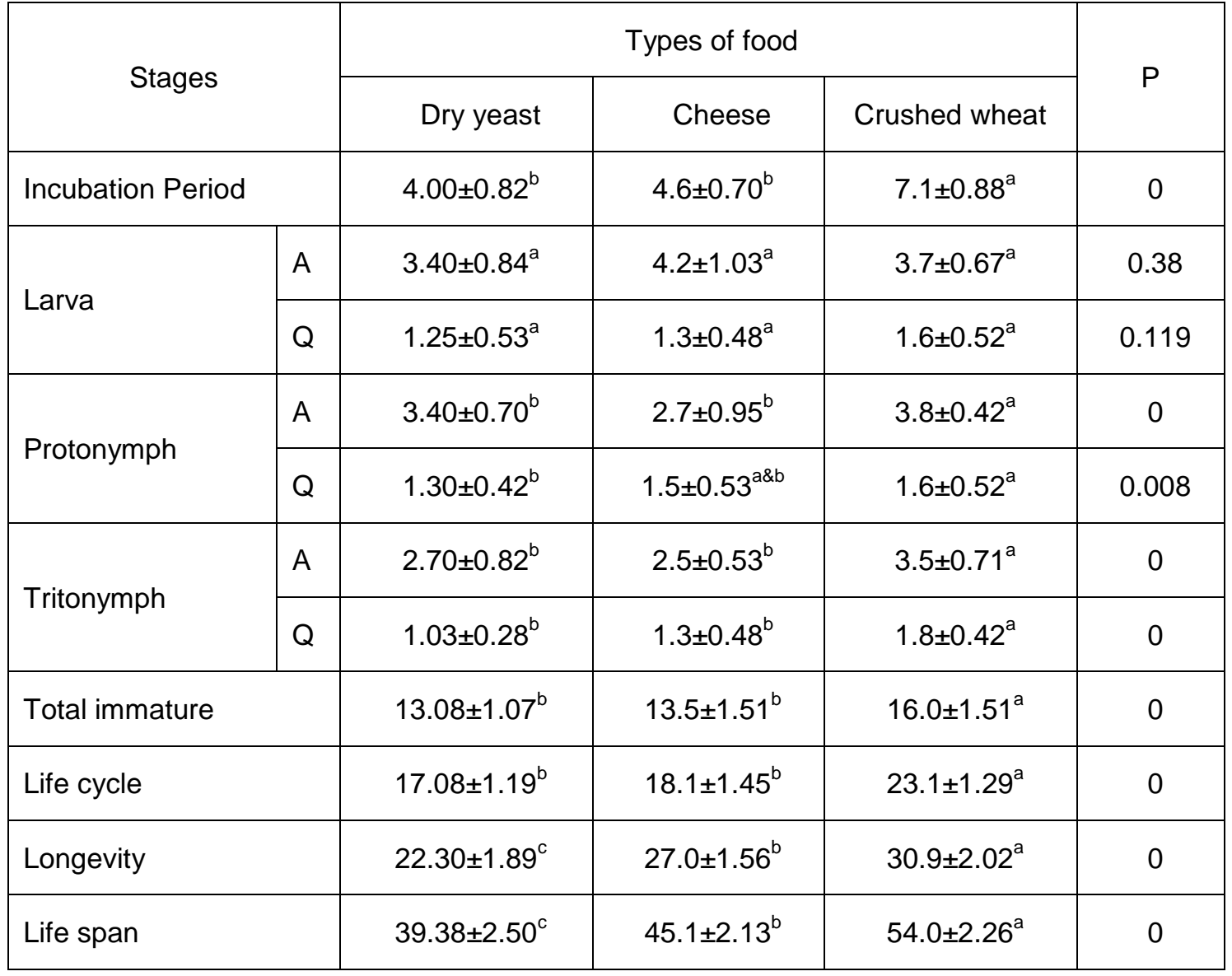

$A=$ Active stage $Q=$ Quiescent stage $P=$ correlation is significant at $P<0.05$

Means in each column followed by the same letter are not significantly different at $5 \%$ level. 
Taha, et al.,

Table (2): Duration of different stages of Rhizoglyphus echinopus male fed on different food types at $25 \mathrm{C}^{\circ}$ and $65 \% \pm 5 \%$ R.H.

\begin{tabular}{|c|c|c|c|c|c|}
\hline \multirow{2}{*}{\multicolumn{2}{|c|}{ Stages }} & \multicolumn{3}{|c|}{ Types of food } & \multirow{2}{*}{$\mathrm{P}$} \\
\hline & & \multirow{2}{*}{$\begin{array}{c}\text { Dry Yeast } \\
3.50 \pm 0.71^{\mathrm{b}}\end{array}$} & \multirow{2}{*}{$\begin{array}{c}\text { Cheese } \\
4.00 \pm 0.82^{b}\end{array}$} & Crushed wheat & \\
\hline \multicolumn{2}{|c|}{ Incubation Period } & & & $4.10 \pm 0.57^{\mathrm{a}}$ & 0 \\
\hline \multirow{2}{*}{ Larva } & $A$ & $3.20 \pm 0.63^{a}$ & $3.00 \pm 0.67^{\mathrm{a}}$ & $3.60 \pm 0.84^{\mathrm{a}}$ & 0.38 \\
\hline & $Q$ & $1.13 \pm 0.29^{a}$ & $1.50 \pm 0.53^{\mathrm{a}}$ & $1.40 \pm 0.52^{\mathrm{a}}$ & 0.119 \\
\hline \multirow{2}{*}{ Protonymph } & $A$ & $3.00 \pm 0.67^{b}$ & $2.80 \pm 0.42^{b}$ & $4.10 \pm 0.74^{a}$ & 0 \\
\hline & $Q$ & $1.10 \pm 0.24^{b}$ & $1.20 \pm 0.42^{\mathrm{a} \& \mathrm{~b}}$ & $1.70 \pm 0.48^{\mathrm{a}}$ & 0.008 \\
\hline \multirow{2}{*}{ Tritonymph } & $A$ & $2.50 \pm 0.71^{b}$ & $2.70 \pm 0.82^{b}$ & $3.60 \pm 0.52^{\mathrm{a}}$ & 0 \\
\hline & $Q$ & $0.98 \pm 0.18^{b}$ & $1.20 \pm 0.42^{b}$ & $1.40 \pm 0.52^{\mathrm{a}}$ & 0 \\
\hline \multicolumn{2}{|c|}{ Total immature } & $11.9 \pm 1.44^{b}$ & $12.4 \pm 1.51^{b}$ & $15.8 \pm 1.14^{\mathrm{a}}$ & 0 \\
\hline \multicolumn{2}{|l|}{ Life cycle } & $15.4 \pm 1.04^{b}$ & $16.4 \pm 1.65^{\mathrm{b}}$ & $19.9 \pm 1.29^{\mathrm{a}}$ & 0 \\
\hline \multicolumn{2}{|l|}{ Longevity } & $18.7 \pm 1.34^{a}$ & $23.9 \pm 1.2^{b}$ & $27.5 \pm 1.08^{c}$ & 0 \\
\hline \multicolumn{2}{|l|}{ Life span } & $34.1 \pm 0.96^{a}$ & $40.3 \pm 1.83^{b}$ & $47.4 \pm 0.97^{c}$ & 0 \\
\hline
\end{tabular}

$A=$ Active stage $Q=$ Quiescent stage $P=$ correlation is significant at $P<0.05$

Means in each column followed by the same letter are not significantly different at $5 \%$ level.

Table (3): Adult female longevity and fecundity of Rhizoglyphus echinopus when fed on different food types at $25 \mathrm{C}^{\circ}$ and $65 \% \pm 5 \%$ R.H.

\begin{tabular}{|c|c|c|c|c|c|c|}
\hline \multirow[b]{2}{*}{$\begin{array}{c}\text { Types of } \\
\text { food }\end{array}$} & \multicolumn{3}{|c|}{ Average duration (days) } & \multirow[b]{2}{*}{$\begin{array}{l}\text { Longevity } \\
\text { (days) }\end{array}$} & \multicolumn{2}{|c|}{ Fecundity } \\
\hline & $\begin{array}{l}\text { Preovi- } \\
\text { position } \\
\text { Period }\end{array}$ & $\begin{array}{c}\text { Ovi- } \\
\text { position } \\
\text { Period }\end{array}$ & $\begin{array}{l}\text { Postovi- } \\
\text { position } \\
\text { period }\end{array}$ & & Total Egg & Daily rate \\
\hline Dry yeast & $3 \pm 0.94^{b}$ & $15.7 \pm 2.06^{\mathrm{C}}$ & $3.6 \pm 0.84^{\mathrm{a} \& \mathrm{~b}}$ & $22.3 \pm 1.89^{\mathrm{C}}$ & $245.4 \pm 18.69^{a}$ & $15.86 \pm 2.3^{\mathrm{a}}$ \\
\hline Cheese & $3.3 \pm 0.82^{a \& b}$ & $20.3 \pm 1.57^{b}$ & $3 \pm 0.67^{b}$ & $26.5 \pm 2.64^{b}$ & $190.8 \pm 17.25^{b}$ & $9.4 \pm 0.73^{b}$ \\
\hline $\begin{array}{c}\text { Crushed } \\
\text { wheat }\end{array}$ & $4 \pm 0.63^{\mathrm{a}}$ & $23.0 \pm 2.19^{\mathrm{a}}$ & $3.9 \pm 0.7^{\mathrm{a}}$ & $30.9 \pm 1.92^{\mathrm{a}}$ & $101.5 \pm 12.53^{\mathrm{C}}$ & $4.4 \pm 0.52^{c}$ \\
\hline$P$ & 0.032 & 0 & 0.038 & 0 & 0 & 0 \\
\hline
\end{tabular}

$A=$ Active stage $Q=$ Quiescent stage

$\mathrm{P}=$ correlation is significant at $\mathrm{P}<0.05$

Means in each column followed by the same letter are not significantly different at $5 \%$ level. 
Life table parameters, Table (4) were affected by the different food types. The dry yeast granules were the shortest mean generation time 24.56 days, while the longest occurred with crushed wheat 28.91 days. The net reproduction time $\left(R_{\circ}\right)$ was the highest value on crushed wheat (61.78) followed by dry yeast (14.63), and the lowest was cheese (11.59). Intrinsic rate of increase $\left(r_{m}\right)$ show the highest value for dry yeast (0.39) and the lowest values was for crushed wheat while, the moderate value was for cheese (0.38). Finite rate of increase $\left(\exp _{\mathrm{rm}}\right)$ also affected by food type showed 1.48 for dry yeast (the highest), 1.46 for cheese (the moderate) and 1.35 for crushed wheat (the lowest). Finally sex ratios (\%female/total) were $0.69,0.68$ and 0.66 also affected by the food types for the same tested food types. These results agree with Mahmoud et al., (2013).

Biochemical analysis of food composition, Table (5) showed that the percentage of the protein content affected the biological aspects of $R$. echinopus, where it was the highest in dry yeast granules (30.36) and lowest in crushed wheat (10.94) while moderate in cheese (24.06) thus; the dry yeast granules proved the most favorable food for the acarid mite $R$. echinopus. The remaining food composition has no clear effect on the biological studies of $R$. echinopus.

Table (4): The effect of different food types on life table parameters of Rhizoglyphus echinopus

\begin{tabular}{|l|c|c|c|}
\hline \multicolumn{1}{|c|}{ Parameters } & Dry Yeast & Cheese & Crushed wheat \\
\hline Net reproduction time $\left(\mathrm{R}_{\mathrm{o}}\right)$ & 14.63 & 11.59 & 61.78 \\
\hline Mean generation time $(\mathrm{T})$ & 24.56 & 24.74 & 28.91 \\
\hline Intrinsic rate of increase $\left(\mathrm{r}_{\mathrm{m}}\right)$ & 0.39 & 0.38 & 0.30 \\
\hline Finite rate of increase $\left(\exp _{\mathrm{rm}}\right)$ & 1.48 & 1.46 & 1.35 \\
\hline Sex ratio (\%female/total) & 0.69 & 0.68 & 0.66 \\
\hline
\end{tabular}

Table (5): Average percentage of different biochemical components of food types.

\begin{tabular}{|l|c|c|c|c|c|}
\hline Food type & Moisture\% & Protein\% & Fats\% & Carbohydrate\% & Ash\% \\
\hline Yeast & 5.5 & 30.63 & 9.47 & 51.43 & 2.97 \\
\hline Cheese & 33.75 & 24.06 & 21 & 15.15 & 6.04 \\
\hline Crushed wheat & 6.15 & 10.94 & 2.61 & 79.67 & 0.63 \\
\hline
\end{tabular}




\section{REFERENCES}

AOAC, (1990). Official Methods of Analysis, 15th ed., Association of Official Chemists,Washington, D.C.34: 2, 303309.

Bielska, I. (1983). Biologia i ekologiadwu gatunk6w roztoczy Z rodzaju Rhizoglyphus -R.echinopus (EI R)I R.robini Clap. Zesz. probl. Post.Naukroln. 252:95-123.

Chmielewski, W (2001). Buckwheat Sprouts as a Food of Rhizoglyphus echinopus (Acari: acaridae) Reared under Laboratory Conditions. The proceeding of the $8^{\text {th }}$ ISB:681-686.

Habashy, M. G. S. (2006). Survey and biological studies on some soil mites in Dakahlia Governorate.M.Sc.Thesis, Fac. of Sci.,Mansoura Unv., 170 PP.

James, C.S. (1995). Analytical Chemistry of foods. Chapmann and Hall, New York.

Lowry, O.H., N.J. Rosenbrough, A.L. Farr and R. J. Randall (1951). Protein measurement with the folin phenol reagent. J Biol. Chem., 193: 265-75.

Mahmoud, I. Hanaa, Horia A. Abd-El Wahab, H. A. Azzouz and Riham H. Ali (2013). Effect of different types of food ondevelopmental stages, fecundity and life table parameters of the acarid mite Rhizoglyphus callae. Egypt. J. Agric. Res., 91 (4): 1-8.

Mathour, S. and M. Dalal (1985). Influence of food quality on the development and growth of the acarid mite, Suidasia nesbiti (Acari: Acaridae). Prog. in Acarology, 2: $231-239$.

Mohamed, A. A. (2003). Studies on some mites associated with cereal and stored products in Egypt. M.sc. Fac. Sci., AlAzher Univ. (Girls), 103 PP.

Mostafa, A. M., F. E. Mohamed, E. M.Yassin and A. A. Mohamed (2006). Occurrence of mite species associated with stored products in Egypt. Egypt. J. Appl. Sci., 21 (12 A) : 227-236.

Pearson, S. (1981). Chemical analysis of food.Edinburgh London, Melbourne and New York.

Putatundia, B. N. (2005). Mites (Acarina) associated with stored food products in Himachol Pradesh, India :A taxonomic study. Journal of Entomological Research. 29(1) : 79-82.

Sallam, G. M., E. M. A. Yassin and N. A. Abdel-Azeim (2007). The predatory insects, mites and spiders of date palm in Rashid region, El-Beheira Governorate, Egypt, $1^{\text {st }}$. Int. Conf. of Date Palm on Integ, Crop Management of Date Palm and its Impact for producing clean and safety Dates, 2-4 September, 2007, Giza, Egypt, Book Abstract.

Schneider, W., G. Hogeboom and H. Ross (1950). Intracellular distribution of enzymes and nucleic acid in normal mouse liver and mouse hepatoma. J. Nati. Cancer Inst., 10: 977-980.

Taha, H. A. (1985). Morphological and biological studies on some mites associated with stored products. Ph. D. Fac. Agric., Al-Azhar Univ., 145 PP.

Taha, H.A., Kawther, S. Abou El Ela, M.M. Abou Setta and Mariam A. El-Sanady. (2002). Effect of diets on Dermatophagoides farinae (Acari: Pyroglyphidae) 2nd Int. Con. of Plant Prot. Res. Institute, Cairo, Egypt, 21-24 Dec., Volume (1): 7-9. 
تأثير أنواع مختلفة من الغذاء علي التطور والخصوية وجداول الحياة للحلم الأكاريدي

\section{Rhizoglyphus echinopus}

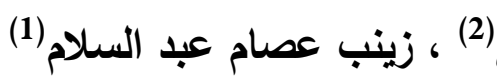

حسن علي طه(1) ، مجدي فوزي(1) ، أحمد السبد الغباشي(2)

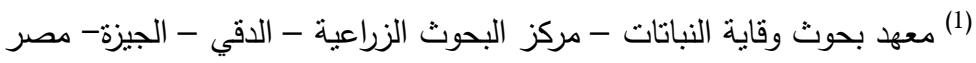

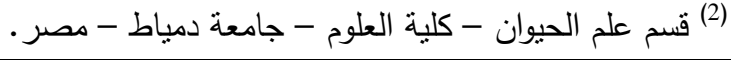

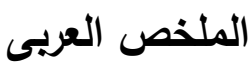

تحت الظروف المعملية ، و عند درجة حرارة 25 مْ و رطوبة نسبية 70 ٪ ، استخدمت ثلاثة أنواع من الغذاء

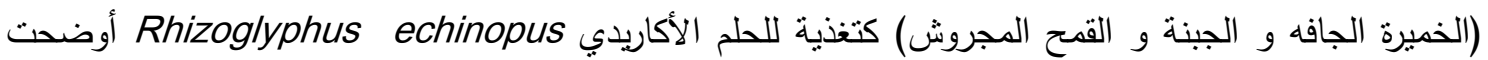
الدراسة أن أطوار النمو، الخصوبة، و جداول الحياة جميعهم تأثروا بإختلاف نوع الغذاء، حيث استغرقت الأطوار غير الكاملة (13,08 / 11,9) ، (13,5 / 12,4) ، (16,00 / 15,8 ) يوما للذكر والأنثي علي التوالي عند التربية علي الغذاء السابق ذكره. بالنسبة لفترة وضع البيض كانت 15,7 و 20,3 و 23,0 يوما و كان متوسط عدد البيض وعدد البيض اليومي ( 145,4 / 15,86) و (190,8 / 9,4) و (101,5 / 4,4 (4,4) علي النوالى. وبعد اجراء التحاليل الكيميائيه لمحتوى انوع الغذاء الثلاثه أثنتت النتائج المتحصل عليها ان التخذية على الخميرة الجافة هى الأكثر نجاحا لتربية الحلم الأكاريدي Rhizoglyphus echinopus معطليا. 
Taha, et al., 